\title{
The Right to Resist an Unlawful Arrest
}

\section{Paul G. Chevigny†}

Conflicts between police and citizens in recent years have achieved increasing notoriety, bringing into prominence the legal problems surrounding the crime of obstructing an officer or resisting arrest. ${ }^{1}$ On the one hand, obstructive tactics such as "going limp" have become a common occurrence in political demonstrations; on the other, police sometimes use resisting arrest and similar charges to "cover" errorsincluding false arrests and the use of excessive force-made during street demonstrations and in individual confrontations. ${ }^{2}$ As the charge of resisting an officer has become more common, the right to resist unlawfully exercised authority has become part of the passionate political conflict over "law and order."3

Last year, Wainwright $v$. New Orleans ${ }^{4}$ presented the Supreme Court with the issue of a citizen's right to resist unwarranted and unlawful police action. The New Orleans police stopped Wainwright, a Tulane law student, allegedly for questioning concerning a murder. When he refused to submit to a search, he was taken into custody and forcibly searched at a police station. Ultimately, he was charged with resisting an officer and breach of the peace by assaulting an officer, charges which arose from his conduct in the police station. The Supreme Court con-

$\dagger$ Staff Attorney, New York Civil Liberties Union. B.A. 1957, Yale University, LL.B. 1960, Harvard University.

1. A typically general statutory provision is that of the N.Y. PENAL LAw $\$ 195.05$ (McKinney 1967):

A person is guilty of obstructing governmental administration when he intentionally obstructs, impairs or perverts the administration of law or other governmental func. tion or prevents or attempts to prevent a public servant from performing an official function, by means of intimidation, physical force or interference, or by means of any independently unlawful act. Obstructing governmental administration is a class $\mathrm{A}$ misdemeanor.

Resisting arrest is separately defined in $\S \S 120.05$ and 205.30 . The crime of assaulting an officer includes elements which may be part of the charge of obstructing or rcsisting an officer, the chief difference being that "obstruction" is made out by a merc refusal to "go quietly" after an arrest, while assault requires an active touching. Other possible charges arising out of conflicts with the police are disorderly conduct, People v. Tinston, 6 Misc. 2d 485, 163 N.Y.S.2d 554 (Magis. Ct. 1957), and even rioting, Commonwealth v. Crotty, 92 Mass. (10 Allen) 403 (1865).

2. Pres. Comm. on Law Enforcement and the Administration of Justice. Task force Report on the Police 182, 195 (1967); E. Cray, The Big Blue Line, chs. I, IV (1966); P. Chevigny, Police Power, passim (1969).

3. In this article the term "right" is used only to mean justification sufficient to reduce or remove criminal liability. It will be argued that patently illegal arrests prescnt such strong provocation that a citizen should not be criminally liable for reasonable resistance.

4. 392 U.S. 598 (1968) (per curiam). 
sidered the breach of the peace charge and the petitioner's claim that the charge resulted from an unlawful arrest.

The Court might have shed some light on the problem of resistance to unlawful police action, but instead it dismissed the writ of certiorari as improvidently granted because the record was inadequate. Two dissenting Justices, Warren and Douglas, intimated that the right to resist an unlawful "seizure of the person" may be basic to the fourth amendment. ${ }^{5}$ The Court as a whole has left the question open with the implied caveat that the issues are serious indeed.

\section{The Right at Common Law}

The dissenting Justices' suggestion that there may be a right to resist an unlawful arrest is consistent with a centuries-old tradition of the common law, both in England and America. ${ }^{\circ}$ Originally, the right was part of the right to resist any unlawful official process. ${ }^{7}$ An action by an official in excess of his authority was a trespass that could be resisted by physical force. The cases frequently treated the trespass as a "provocation," which would justify an assault, or, if the officer were killed, would reduce the crime from murder to manslaughter.

The law was still unsettled in 1666. In Hopkin Huggett's Case ${ }^{8}$ the defendant and others had killed a constable who was illegally attempting to impress a man into the army. The judges disagreed whether the crime was murder or manslaughter because the victim of the impressment apparently offered no resistance, but the majority said

that if a man be unduly arrested or restrained of his liberty by three men, altho' he be quiet himself, and do not endeavor any rescue, yet this is a provocation to all other men of England, not only his friends but strangers also for common humanity sake, as my Lord Bridgman said, to endeavor his rescue. ${ }^{3}$

The Queen $v$. Tooley ${ }^{10}$ firmly established the right to resist an unlawful arrest. A constable tried to arrest one Anne Dekins either because she

5. Justice Warren thought that Wainwright's arrest was clearly illegal, but he felt that the Supreme Court did not need to reach the problem of the petitioner's constitu. tional right to resist because Louisiana law explicitly gave him such a right. See City of Monroe v. Ducas, 203 La. 974, 14 So. 2d 781 (1943).

6. See 4 AMr. Jur. Arrest $\S 92$ (1936); 5 Axr. Jur. 20 Arrest $\S 93$ (1962); J. Turver, 1 Russell on CrIME 511 et seq. (IIth ed. 1958) [hereinafter cited as TURNER].

7. See Annot., 10 A.L.R.3d 1146 (1966).

8. 84 Eng. Rep. 1082 (K.B. 1666).

9. Id.

10. 2 Ld. Raym. 1297, 92 Eng. Rep. 349 (K.B. 1710). 
was suspected of being disorderly or had been disorderly at some time in the past, though she was not disorderly at the time she was arrested. The defendants interfered in the arrest, killing the constable. The charge of murder was reduced to manslaughter because:

[A] man ought to be concerned for Magna Charta and the laws, and if anyone against the law imprison a man, he is an offender against Magna Charta. We seven hold this to be sufficient provocation, and we have good authority for it: in Hopkin Huggett's case ... (and the case is stronger than that). ${ }^{11}$

In applying this rationale to cases of assault, the English judges ruled that the provocation of an unlawful arrest did not simply reduce the degree of the crime, as it did in the case of homicide, but rather excused the assault altogether..$^{12}$ For example, the courts excused an assault on a constable who attempted to arrest a journeyman because his master "suspected that he had tools of his, and was leaving his work undone,"13 and an assault on a constable who sought to arrest a man for "insulting" a third-party complainant. ${ }^{14}$ Such cases present instances of obviously unlawful arrests in which there was not only no probable cause, but apparently no offense at all.

The courts had no problems in such cases because there was clear provocation, but cases involving mere technical defects in the arrest were another matter. In The King v. Mead, ${ }^{16}$ a conviction for assaulting a bailiff with an axe was reversed because the bailiff had not lawfully arrested the defendant; he had shown a proper warrant, but not the underlying writ.

But English authorities eventually recognized that resistance should not be excused in cases like Mead where there was no real provocation. The judges in The Queen $v$. Davis ${ }^{16}$ finally held that the Tooley decision did not require a finding of provocation as a matter of law in

11. 92 Eng. Rep. at 352.

12. In California it has been held recently that a statute abolishing the common law right to resist an unlawful arrest may have the effect merely of reducing the degree of crime for assaulting an officer from a felony to a misdemeanor. See People v. Curtis, - Cal. -, 74 Cal. Rptr. 713, 450 P.2d 33 (1969).

13. The King v. Thompson, 168 Eng. Rep. 1193 (K.B. 1825).

14. The King v. Curvan, 168 Eng. Rep. 1213 (K.B. 1826). In this case and in The King $v$. Thompson, supra note 13 , the defendant resisted with a deadly wcapon, whlch would not be justifiable under later English law. See 1 TuRner, supra note 6, at 511; The Queen v. Wilson, 1 W.L.R. 493 (1955).

15. 2 Stark. 205 (1817). See also The King v. Patience, 173 Eng. Rep. 398 (1837), in which the defendant resisted a warrant executed by the constable's son.

16. I Leigh \& Cave's C.C. Res. 64 (Camarthen Assizes 1861). The debate among the English commentators is traced in 1 TURNER, supra note 6, at 508-511. 
every case where there was an illegal arrest. Davis was charged with the murder of a constable who was executing a warrant which contained only some highly technical defects. Justice Blackburn said:

This principle seems the one recognized in Roger's case ...; where it was ruled by Lord Hardwicke that, provided the process be not defective in the frame of it, and be issued by a Court or magistrate having jurisdiction in the case, the killing of a minister of justice in the execution of it will be murder, although there may have been error or irregularity in the proceeding previous to issuing the process; for the officer must at his peril pay obedience to it. ${ }^{17}$

Further criticism and analysis of the early common law rule led to other modifications. It was held, for example, that resistance which occurred some time after the arrest was unjustified, partly because the provocation was reduced once the defendant had time to reflect. ${ }^{18}$

The English courts thus arrived at certain basic distinctions essential to an understanding of the law of resistance to unlawful official action. A legal process which is valid "on its face" must be obeyed, but one that is patently unlawful is such a provocation to the citizen that the criminal element in his resistance is reduced, if not removed entirely. The distinction is sometimes a difficult one to apply, but it is a useful guide. Any "provocation" to the defendant in Davis, where the warrant contained only minor defects, is doubtful. In most of the cases in which provocation was recognized, however, the arrests were of the most outrageous kind: impressment of a soldier, ${ }^{10}$ arrest on suspicion of being disorderly, ${ }^{20}$ arrest for refusal to finish work, ${ }^{21}$ or arrest on suspicion of making an insult. ${ }^{22}$ The arrests were simply arbitrary assertions of authority, and the English courts felt that a free man should not be penalized for resisting such affronts.

American courts adopted the English rule that unlawful arrest was a provocation to resist, although, as in England, many of the older cases tended to define any defect in the process as a provocation. Other courts attempted to limit lawful resistance to legal processes that were "bad on

17. 1 Leigh \& Cave's C.C. Res. at 75.

18. I TURNER 508. Accord, People v. McNeil, 15 N.Y.2d 717, 256 N.Y.S.2d 614, 204 N.E.2d 648 (1965).

19. Hopkin Huggett's Case, 84 Eng. Rep. 1082 (R.B. 1660).

20. The Queen v. Tooley, 2 Ld. Rajm. 1297, 92 Eng. Rep. 349 (K.B. 1710).

21. The King v. Thompson, 168 Eng. Rep. 1193 (K.B. 1825).

22. The King v. Curvan, 168 Eng. Rep. 1213 (K.B. 1826). It is perhaps significant that in all these cases the existence of any underlying offense was doubtful. In at least two of them, the impressment and the arrest of the journejman, there was an element of social oppression which may have increased the provocation. 
their face," with illogical results. ${ }^{23}$ Some courts, however, adopted the more rational rule that evolved from the English cases. In the nineteenth century, federal judges attempted a rough differentiation between legal process that was apparently regular and that which was patently arbitrary. Two cases from the District of Columbia Circuit exemplify the American law. The defendant in United States $v$. Thompson ${ }^{24}$ was charged with assault and battery on a marshal attempting to execute a warrant. The warrant was void because the justice had signed it in pencil and because the act charged had been committed outside the justice's territorial jurisdiction, although this was not apparent on the warrant's face. There seems to have been no question but that the underlying offense, beating a slave, was in fact committed. The court held that if the warrant contains on its face a cause of arrest within the jurisdiction of the magistrate, "purports to have been issued within his jurisdiction, and is in other respects formal," the officer is bound to execute it, and the defendant may not lawfully resist. ${ }^{25}$ United States $v$. Goure, ${ }^{26}$ eleven years later, presents a quite different result. The officers arrested Goure, without a warrant, because they "believed" him to be "a loose and disorderly person without any visible means of livehood, a nightwalker, a frequenter of bawdy-houses and a keeper of false keys." ${ }^{27}$ When they stopped and searched Goure, he resisted and threatened their lives. He was charged with intimidating officers in the discharge of official duties, but the court held that the officers were acting beyond the scope of their cluties.

In the nineteenth century, both American and English courts reached the same conclusions concerning the right to resist unlawful arrest: an assertion of arbitrary authority was a provocation to resist. This concept of provocation is still vital today.

\section{Criticism of the Right to Resist}

Of late, the common law rule has fallen into disfavor with many lawyers for what are felt to be practical reasons. The decline of the

23. See Annot., 10 A.L.R.3d 1146 (1966). Many of the cases differed on when process was void on its face, often with doubtful results. The New Hanpshire Supreme Court, for instance, held that an "officer will not be protected because he is acting by virtuc of papers which it is apparent from their inspection have no legal vitality." As an cxam. ple of such papers, the court cited a warrant without a seal. State v. Wecd, 21 N.11. 262, 269 (1850). Cf. Wright v. Comm., 8 Ky. L. Rptr. 718, 2 S.W. 904 (Ct. App. 1887); Creighton v. Comm., 84 Ky. 103 (1883); State v. Curtis, 2 N.C. 471 (1797). But cf. People ex rel. Frierson v. Pate, 344 F.2d 588, 590 (7th Cir. 1965).

24. 28 F. Cas. 89 (No. 16,484) (C.C.D.C. 1823).

25. Id. at 90 .

26. 25 F. Cas. 1381 (No. 15,240) (C.C.D.C. 1834).

27. Id. 
common law rule dates at least from Professor Warner's attack in the forties. ${ }^{28}$ After a spirited debate in 1958, the American Law Institute rejected the right to resist unlawful arrest altogether:

The use of force is not justifiable ...: (l) to resist an arrest which the actor knows is being made by a peace officer, although the arrest is unlawful . . . .29

The right has been abolished by the legislature in at least six states, ${ }^{30}$ most recently in New York, where the so-called "no-sock" law was passed as a rider to a bill strengthening the right of the police to use deadly force. ${ }^{31}$ Some state and federal judges have also condemned the right, ${ }^{32}$ most recently the Second Circuit which suggested, in 1967, that the right to resist was "waning." 33

Indeed, recognition of the right has waned in the face of almost universal criticism, although the increasing notoriety of police abuses makes this development somerwhat puzzling. Academic and judicial condemnation, furthermore, has obscured the continuing vitality of what has been the law for at least three hundred years. Critics of the common law rule regard it as a vestige of a more brutal age when society could tolerate street altercations between officers and citizens and when a citizen deprived of constitutional rights had no effective redress. Nowadays, it is argued, the rough-and-tumble social climate that supported the right is gone. As the New Jersey Superior Court said:

The concept of self-help is in decline. It is antisocial in an urbanized society. It is potentially dangerous to all involved. It is no longer necessary because of the legal remedies available. ${ }^{34}$

To assert that adequate legal remedies now exist to redress false arrests and other police abuses is to misconstrue the rationale of the right. The right does not exist to encourage citizens to resist, but

28. Warner, The Uniform Arrest Act, 28 VA. L. REv. 315, 330 (1942). Sce, e.g., Notc. The Right to Resist an Unlawful Arrest: An Outdated Concepl?, 3 Tulst L.J. 40 (1965).

29. Model Penal Code \$ 3.04(2)(a) (Tent. Draft No. 8, 1958). Reasonable ignorance of the fact that the person making the arrest was a peace officer would be a defense to the charge under this section.

30. Cal. Penal Code $\S 834 a$ (West. Supp. 1968); Del. Code ANN. Title II, \& 190j (1951); ILL. ANN. STAT. ch. 38, \& 7-7 (Smith-Hurd 1961); N.H. REv. STat. ANv. 5945 (1955): N.Y. Penal Law \$ 35.27 (McKinney Supp. 1968); R.Y. GeN. Laws ANs. 12-7-10 (1911).

31. N.Y. PENAL LAW \$ 35.27 (McKinney Supp. 1968).

32. The New Jersey Superior Court rejected the common-law rule in an unusual instance of prospective decision-making. State v. Koonce, 89 N.J. Super. 169. 214 A.2d 428 (App. Div. 1965).

33. United States v. Heliczer, 373 F.2d 241, 246n. (2d Cir. 1907).

34. State v. Koonce, 89 N.J. Super 169, 184, 214 A.2d 428, 436 (App. Div. 1965). 
rather to protect those provoked into resistance by unlawful arrests. In the excitement of an arrest, a person is likely to respond to his emotions, and if his impulse to resist is provoked by arbitrary police behavior, it is fundamentally unfair to punish him for giving in to that impulse with measured resistance.

Even were one to accept the theory that other remedies may be substitutes for the right to resist, the rationale of the right is not undermined unless those alternative remedies are real ones. Few critics have examined the adequacy of the alternative remedies on which they have relied, but a cursory overview suggests that each of them is seriously deficient.

Bail. At one time bail was nearly impossible to obtain, and the danger of fatal disease in prison was great-giving an 18th-century defendant particular reason to fear arrest. ${ }^{35}$ Although bail is now frequently available and incarceration does not often result in death, the bail system still does not protect a substantial number of defendants. A recent survey revealed that nearly half the defendants in a sample of cases pending before the New York City courts remained in jail prior to trial. ${ }^{36}$ Many lose their jobs as a result. And even if an individual is released on bail, he will have been subjected to the expense of paying a bondsman and to the stigma of arrest, which, in the case of minor offenses, may have consequences as serious as those of conviction. When these considerations are combined with the great delay and congestion in urban criminal courts, bail hardly seems an adequate remedy.

Procedural safeguards. That constitutional rights are more scrupulously protected now than they were in the past, according to some, reduces the cause for resistance. ${ }^{37}$ Assuming the dubious proposition that later procedural protections affect the thinking of persons at the time of arrest, ${ }^{38}$ however, such protections are realizable only if the

35. Comment, The Right to Resist an Unlawful Arrest, 7 Naturat Res. L.J. 119, 128 (1967).

36. Foote, $A$ Study of the Administration of Bail in New York City, 106 U. PA. L. REv. 693, 707 (1968). See also R. Goldfarb, Ransom: A Critique of the Ameriann Ball System, ch. II (1965).

37. For example, it has been argued that before Mapp v. Ohio, 367 U.S. 343 (1961) some defendants were motivated to resist unlawful arrest in order to prevent contraband from being taken from their person by the arresting officer. Since such evidence would now be excluded, that motive is said to be gone. N.Y. State Combined Council of Law Enforcement Officials, Memorandum, Re: An Act to Amend the Code of Criminal Pro. cedure in Relation to the Use of Force in Resisting Arrest, Feb. 23, 1965.

In a similar vein, Professor Warner argued that only a guilty man has a motive to resist; the innocent defendant will be eager to establish his innocence. Warner, The Uniform Arrest Act, supra note 28.

38. See pp. 1136-37 infra. 
defendant has some reliable way of showing that the police acted unconstitutionally. As recent research has shown, defendants usually have no such proof. For example, if police search illegally and make an arrest based on the evidence obtained thereby, policemen may testify in such a way as to make the evidence appear to have been lawfully seized. ${ }^{39}$ The existence of procedural safeguards is thus unlikely to inspire the confidence necessary to eliminate the rationale of the right to resist.

Administrative remedies. Recent studies have shown that administrative review of police abuses tends to be futile. Despite the enormous clamor over police review in the last few years, it is still true that most police departments do not have any well-developed complaint procedures. They possess neither specialized staffs nor hearing procedures for such complaints, ${ }^{40}$ and even in cities like New York, where such procedures are long-established, most complaints are found to be unsubstantiated for lack of corroboration. ${ }^{41}$

Injunction. A civil injunction theoretically can reach systematic abuses, the very ones with which administrative complaint procedures are least able to cope. An injunction against unlawful police action will usually not be granted, however, unless there is such a clearly provable pattern or policy that a repetition of the abuse can be expected, ${ }^{42}$ and except in the most extraordinary cases, ${ }^{43}$ no such pattern or policy can be proved. It is very likely that most police abuses do not fall into patterns definite enough to be enjoined, and that most of them are contrary to department policy.

Civil damages. A damage action is the logical remedy for the individual abuse that is not enjoinable, but it is not a remedy that will solve the problems of most people falsely arrested. The action may take several years, and the plaintiff may have a difficult time finding a

39. Note, Effect of Mapp v. Ohio on Police Search and Scizure Practices in Narcolics cases, 8 ColuM. J. LAw \& Soc. Prob. 87 (1968).

40. Note, Administration of Complaints by Civilians Against Police, 78 Harv. L. REv.

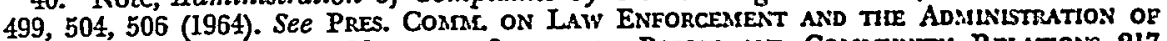
Justice, fietd Survey V: National Survey of Police ANd Cosarunity Relations 217 (1967).

41. P. Chevigny, Police Power, ch. 14 (1969). Even more difficult are cases "in which the actions of the officer are clearly illegal or improper but are consistent with prevailing practices of a department." Pres. CoMsr. ON LAW ENFOrCenient AND thiE ADMin. OF JUSTICE, TASK FORCE REPORT ON THE POLICE 28-29 (1967).

42. See Note, The Federal Injunction as a Remedy for Unconstitutional Police Conduct, 78 YALE L.J. 143, 146 (1968).

43. See, e.g., Hague v. C.I.O., 307 U.S. 496 (1939); Lankford v. Gelston, 364 F.2d 197 (4th Cir. 1966) (en banc). 
lawyer willing to spend the necessary time on his case unless he has been injured badly enough to give rise to large damages.

Such are the remedies ordinarily available to the modern citizen against a false arrest. ${ }^{44}$ They would probably not, by themselves, be enough to induce him to accept his detention in silence. The critics of the right to resist, quite properly, rely on more intangible considerations. In contrasting the days when the right came into being with our own enlightened times, it is said that the right is now "artificial" or futile. ${ }^{45}$ The weapons of law enforcement today are so powerful that the citizen can hardly hope to escape arrest-an attempt usually leads to injury, and the citizen almost always gets the worse of it. Perhaps most important, the legality of an arrest may be a highly technical matter, "often a matter of close debate as to which even lawyers and judges may differ," 46 and a citizen ought not to try to settle the question by resistance in the street. As the court said in State v. Koonce:

$[\mathrm{P}]$ olice officers attempting in good faith, although mistakenly, to perform their duties in effecting an arrest should be relieved of the threat of physical harm at the hand of the arrestee. ${ }^{47}$

The critics' arguments boil down to one central point: constituted authority is now sufficiently civilized that citizens should deal with it peacefully. Violence only encourages disrespect for law.

The argument that an arrest is a technical matter, its validity to be settled in the courts rather than on the streets, will be extensively analyzed in the pages that follow. The legality of some arrests is indeed a matter of dispute, but others are obviously illegal. The question really is whether there is a workable rule to distinguish the classes of unlawful arrests that may be resisted from other unlawful arrests.

The "futility-of-the-resistance" argument seems beside the point, in the same way that the adequacy of the alternative remedies for police abuse is beside the point. Surely, when obeying the impulse to resist official abuse, most citizens do not consider the likelihood that they will successfully avoid arrest, any more than they consider the cost in jail time awaiting trial if they are arrested. As the Court of Appeals of New York said in 1954:

44. Criminal proceedings against the officer are not available in the usual casc because "false arrest" is not a crime. Certain specialized types of false arrests, such as those intended to enforce a pattern of segregation, may be federal crimes, 18 U.S.C. $\$ 245$ (1968).

45. Comment, 7 Natural Res. L.J. 119, supra note 35, at 125. See also authorities citcd note 28 supra.

46. State v. Koonce, 89 N.J. Super. 169, 184, 214 A.2d 428, 436 (1965).

47. Id. 
For most people, an illegal arrest is an outrageous affront and intrusion - the more offensive because under color of law-to be resisted as energetically as a violent assault. ${ }^{48}$

And as long ago as 1710 the King's Bench used equally strong words:

The prisoners in this case had sufficient provocation; for if one be imprisoned upon an unlawful authority, it is a sufficient provocation to all people out of compassion, much more where it is done under a colour of justice, and where the liberty of the subject is invaded, it is a provocation to all the subjects of England.99

The decision to resist is the work of a moment rather than the result of carefully considered alternatives. The real question is whether for this act of resistance the citizen ought to be convicted of a crime.

Commentators have treated the question of whether there is a right to resist unlawful arrest as a narrorvly prudential one: Are the potential harms to the officer and citizen justified in light of the available alternatives? Such a formulation assumes that there is no "right" to resist. The existence of other rights, such as the right to remain silent or to be free from unlawful searches, does not depend upon whether it is prudent for the individual to assert them. Such rights are preserved because our experience has been that to ignore them encourages offcial abuses. Citizens feel that a government which abuses them is tyrannical. ${ }^{50}$ The question is whether such a sense of injustice lies behind the preservation of the right to resist.

To anyone who values his personal liberty and possesses a sense of justice, the openly arbitrary assertion of official power is an "outrageous affront." Anglo-American case law recognized the existence of this affront and concluded that it justified the right to resist. To understand the values which gave rise to the right, it is necessary to consider the period during which the right came to be recognized in England. It was during this period, the English revolution (1666-1710), that common citizens first began to recognize that they had rights of personal liberty against the lords and the Crown. ${ }^{51}$ The right to resist unlawful arrest memorializes one of the principal elements in the heritage of the English revolution: the belief that the will to resist arbitrary authority in a reasonable way is valuable and ought not to be suppressed by the criminal law. In the face of obvious injustice, one ought not to be

48. People v. Cherry, 307 N.Y. 308, 311, 121 N.E.2d 238, 240 (1954).

49. The Queen v. Tooley, 2 Ld. Raym. 1297, 92 Eng. Rep. 349,352 (K.B. I7I0).

50. See L. LEVY, ORIGINS OF THE FIFTH AMreNdMeNT passim (1967).

51. Id., chs. ix, $\mathrm{x}$. 
forced to submit and swallow one's sense of justice. More importantly, it is unconscionable to convict a man for resisting an injustice. This is indeed a value judgment, but the values are fundamental.

\section{Dimensions of the Right}

The common law history and the theory of provocation imply that conviction of a defendant for reasonable resistance to an unlawful arrest may be a denial of due process of law. English and American courts have sometimes relied on this constitutional dimension without much reflection or analysis..$^{52}$ There are three possible constitutional rationales upon which the right may be based.

Vindication of constitutional rights. In a limited category of cases, reasonable resistance may be essential to the vindication of certain constitutional rights. First amendment rights, in particular, may need such protection. The police frequently arrest political demonstrators even though the demonstrators are acting lawfully. These arrests are often patently illegal, and mild resistance is not uncommon. Resistance, such as going limp, is part of the effort to continue the lawful demonstration. Arrests under these circumstances may be highly provocative, but provocation is not the issue here; reasonable resistance should be legitimated in order to protect the first amendment freedom. Were there no right to resist such arrests, the resisting arrest statute would afford the police an easy tool for curbing the exercise of first amendment rights. Whenever a lawful arrest for demonstrating might be barred by the first amendment, the simplest thing for the police to clo would be to arrest the demonstrators unlawfully. The demonstration would then be terminated with little risk of consequences to the police; those who resisted could be convicted of obstructing an officer, while those who submitted would necessarily cease the conduct found offensive by the authorities. As applied to warrantless arrests which patently violate first amendment rights, therefore, any statute which limits the common law right to resist should be held unconstitutional.

52. The leading English case, The Queen v. Tooley, 2 Ld. Raym. 1297, 92 Eng. Rep. 349 (K.B. 1710), traced the right to the Magna Charta, see p. 1130 supra. Many American authorities have assumed that the right is implied in the Constitution. See Pcople v. Raffery, 69 Ill. 111, 112 (1873); Kansas City v. Mathis, 409 S.W.2d 280 (K.C. Ct. App. Mo. 1966); City of Monroe v. Ducas, 203 La. 971, 14 So. 2d 781 (1943); City of Columbus v. Holmes, 152 N.E.2d 301 (Franklin County Ct. App. Ohio 1958), aff'd per curiam, 169 Ohio St. 251, 159 N.E.2d 232 (1959). The United States Supreme Court once said, in dictum, that "one has an undoubted right to resist an unlawful arrest." United States v. DiRe, 332 U.S. 581, 594 (1948). See also John Bad Elk v. United States, 177 U.S. 529 $(1900)$, which held that under common law the killing of a policeman in resistance to an unlawful arrest could be manslaughter. 
Disobedience to an unlawful order. The Supreme Court has also acknowledged that due process protects an individual from being punished for violating an arbitrary police order..$^{63}$ An arrest is closely related to such an order-both are powers of the State to which an individual must ordinarily submit. It might even be argued that an arrest is an order to the defendant to submit himself to police custody. If an individual cannot be convicted for not submitting to an illegal order, he should not be convicted for not submitting to an illegal arrest. The Supreme Court, however, has not fully explained how conviction for failing to obey an unlawful order violates due process; thus, while the doctrine is a useful analogy to the situation of an unlawful arrest, it does not definitively establish the right to resist.

Provocative arrests. Finally, and most importantly, due process should not permit provocation by the police to be rewarded by a conviction for resisting arrest. If the state's agent provokes an individual into committing a crime, the state should not convict or punish him for committing that crime. In some cases, provocation may constitute entrapment. For the state to convict an individual for a crime which it has provoked violates the fundamental fairness which due process is designed to protect. Moreover, it encourages the police to engage in offensive practices.

The right to resist may be viewred as a common law right as well as a constitutional right. Until the Supreme Court carefully articulates the constitutional dimensions, state courts and legislatures should protect the common law right of a citizen to use reasonable resistance when provoked by arbitrary authority.

In defining reasonable resistance, however, courts and legislatures might be inclined to draw a distinction between resistance that is passive and resistance that is affrmative. One might, for example, be permitted to refuse the unlawful order of a policeman without being permitted to use affirmative force in resistance. This may at first seem an attractive balance between the important right to resist arbitrary authority and the need to protect policemen from injury, but further reflection will show that it is unworkable. In the first place, such a rule conflicts with the present law of resisting or obstructing an officer. The

53. See Shuttlesworth v. City of Birmingham, 382 U.S. 87 (1965) (reversed conviction for obstructing the sidewalk by refusing to move when so ordered): Wright $v$. Gcorgia, 373 U.S. 284 (1963) (reversed conviction for refusal to obey an order to leave a segregated basketball court). Mír. Justice Douglas relied upon IVright in his dissenting opinion in Wainwright v. New Orleans, 392 U.S. 598 (1968). 
tendency of recent years has been to define any physical form of refusal to submit, including sitting down or refusing to move, as "resistance." 54 If that were the only problem, an alluring solution might be to hold that resisting arrest statutes cannot constitutionally be applied to purely passive resistance to a patently unlawful arrest. ${ }^{60}$ But a more serious difficulty is the problem of distinguishing passive physical resistance from affirmative resistance. If the police attempt to handcuff their prisoner, is he justified in pulling his wrists away or in folding his arms? If the officer strikes him to make him submit, is he justified in warding off the blows or trying to grasp the officer's arm?

While the distinction between affirmative and passive resistance is often blurred, courts have been able to determine rough standards for measuring the reasonable use of force in resisting an unlawful arrest. To take an example, the majority of American and English courts have held that the use of a deadly weapon is unreasonable in resisting a detention not itself accompanied by the use of deadly force, and that an assault charge based upon the use of such a weapon is usually valid. ${ }^{57}$ This rule sets an outer limit to the force which may be used in resistance. The question at issue, whether the defendant had and used a deadly weapon, is relatively concrete and easier to determine than, for example, the question of whether the defendant merely pushed the policeman or punched him. ${ }^{.8}$

54. See In Re Bacon, 240 Cal. App. 34, 49 Cal. Rptr. 322 (1966); People v. Crayton, 55 Misc. 2d 213, 284 N.Y.S.2d 672 (App. Div. 1967); People v. Knight, 35 Misc. 2d 216, 228 N.Y.S.2d 981 (Magis. Ct. 1963). See also Note, Types of Activity Encompassed by the Offense of Obstructing a Public Officer, 108 U. PA. L. REv. 388 (1960).

55. Something of this rationale underlies District of Columbia v. Little, 339 U.S. 1 (1950). See also Note, Types of Activity Encompassed by the Offense of Obstructing a Public Officer, 108 U. PA. L. Rev. 388 (1960); note 58 infra.

56. Most courts would probably hold that such resistance is justified on the theory that a prisoner can lawfully use enough force to prevent himself from being injured while being taken into custody. Note, Force That May Be Used to Resist an Unlawful Arrest, 9 OKLA. L. REv. 60 (1956).

57. State v. Mox Mox, 28 Idaho 176, 152 P. 802 (1915); State v. Goering, 193 Kan. 307, 392 P.2d 930 (1964); People v. Briggs, 19 N.Y.2d 37, 224 N.E.2d 93, 277 N.Y.S.2d 662 (1966); State v. Gum, 68 W. Va. 105, 69 S.E. 463 (1910). But see Pickett v. State, 25 S.E. 608 (Ga. Sup. Ct. 1896); Note, Force That May Be Used to Resist an Illegal Arrcst, 9 OKLA. L. REv. 60 (1956).

58. This discussion is not intended to imply that the concept of passive resistance is not useful as a defense in those rare cases in which such resistance can actually be proved. In New York, for example, the current state of the law lends itself to such a distinction. The New York statute eliminating the right to resist an unlawful arrest states that "[a] person may not use physical force to resist an arrest, whether authorized or unauthorizcd,", 39 N.Y. PENAL LAw \& 35.27 (McKinney Supp. 1968) (emphasis added). Curiously, the resisting arrest statute penalizes only persons who resist an "unauthorized arrest," N.Y. Penal Law $\$ 205.30$ (McKinney 1967). A lawful arrest is thus still an clement of the crime of resisting arrest and presumably one may not be convicted for resisting arrest without the use of physical force if the arrest is unauthorized. The statute defining the crime of assault does not mention authorized arrest. N.X. PENAL LAw $\$ \S 120.00-120.35$ (McKinncy 1967). Presumably one may be convicted for resistance which amounts to assault, whether 


\section{Determining Provocation}

If it is clear that reasonable resistance to unlawful arrest cannot be limited to passive resistance, there is still the problem of defining and explaining what kinds of unlawful arrests are so provocative that resistance must be excused. The problem must be dealt with on several levels, depending upon how patently unlawful the arrest is, either by constitutional or by common law standards. Unlawful arrests may be divided into three categories : (A) the easiest case, an arrest that prevents a citizen from exercising his constitutional rights; (B) unlawful arrests based upon conduct in the presence of the arresting officer; and (C) unlawful arrests based on incidents not witnessed by the arresting officer.

\section{A. Infringement of Constitutional Rights}

Resisting an unlawful arrest is often necessary to protect first amendment rights, regardless of whether the resistance is provoked. ${ }^{5}$ But any arrest which infringes on constitutional rights is likely to be provocative by common law standards. For example, in a recent case several Negroes were playing basketball on segregated public facilities, and refused to leave the premises after being ordered to do so by the police. ${ }^{60}$ Their subsequent arrest for disobeying the officers' order deprived them of their right to equal protection of the law and would have caused a great many defendants to offer some resistance.

Every false arrest raises a fourth amendment question because it is by definition an unlawful "seizure." The impairment of fourth amendment rights, however, is not enough to justify resistance to an unlawful arrest. The problem is to determine the circumstances under which such a seizure becomes so provocative as to make unfair the imposition of a criminal penalty for resisting it. State courts have gen-

or not the arrest was authorized. The interrelation of these statutes has given rise to a ruling that resistance to an unlawful arrest that does not amount to an ascault may not be penalized. People v. Walgren, No. 89744/68 (New York City Crim. Ct. Manlattan. Part 2B3, April 14, 1969) (Midonick, J.). A similar reasoning was applied in California in People v. Curtis, - Cal. - 74 Cal. Rptr. 713, 450 P.2d 33 (1969) to reduce a change from felony to misdemeanor assault, because the felony required assault on an officer in the discharge of his duties. In Walgren the defendant "resisted" an unlawful arrest by cscap. ing from the officer's grasp and running away. The court acquitted him of the clarge of resisting arrest, saying that an interpretation of the law that vould penalize such an action would give rise to serious constitutional questions. This reasoning secms correct as far as it goes. The problem is that the constitutional questions would be just as serious if the officer's grasp had been firmer, and the defendant had pushed him in order to make good his escape. Such are the tortured decisions produced by the cffort to do justice when the right to resist is abolished.

59. See p. 1138 supra.

60. Wright v. Georgia, 373 U.S. 284 (1963). 
erally protected the right to resist an arrest resulting from an illegal intrusion on one's real property with more tenderness than the right to resist an unlawful arrest made in a public place. There is an extra element of provocation when the police come onto a person's own land for an unlawful purpose. ${ }^{01}$ When the intrusion is accompanied by an unlawful search, the courts are obliged to decide whether resistance is an appropriate means for protecting federal constitutional rights. ${ }^{02}$ When the search is patently unlawful, the courts have protected the right to resist, ${ }^{63}$ but when the officer possesses a warrant that is valid on its face, resistance is generally not justified. ${ }^{64}$

The recent decision in Terry $v$. Ohio ${ }^{65}$ complicates the determination of when a search is patently illegal. The Supreme Court held in Terry that when a police officer has "reasonable suspicion" that an individual has committed or is planning a serious crime, he may detain that individual on the street for purposes of questioning and may pat down the suspect's outer clothing to detect weapons. It is plain that resistance to such a legitimate detention may be made a criminal offense, 68 but the term "reasonable suspicion" is so vague that the individual who is detained under a "stop and frisk" may not have a clear idea whether the officer is justified in detaining him. Not knowing, for example, that the police are looking for some one of his general description, he might resist detention when an officer stops him for questioning even though the officer does have reasonable suspicion.

It is too early yet to tell if Terry will make it more difficult to determine whether provocation actually exists, but the problem really stems from the vagueness of the Terry standard. Once judicial decisions flesh out the standard, courts will be better able to distinguish unlawful detentions, and individuals may have a better idea of when a detention is legal. In the meantime there is some evidence that Terry

61. State v. Cesero, 146 Conn. 375, 151 A.2d 338 (1959); King v. State, 140 So. 2d 482 (Miss. 1963); Pettis v. State, 48 So. 2d 355 (Miss. 1950); Masden v. State, 244 S.W.2d 228 (Tex. 1951); State v. Hooker, 17 Vt. 658 (1845).

62. When an individual resists a search, he is, of course, not resisting an arrest. However the charge preferred against him will be very similar to resisting arrest, $e . g$, obstructing an officer.

63. Dovel v. United States, 299 F. 948 (7th Cir. 1924); Jackson v. State, 87 Fla. 202, 99 So. 548 (1924). Cf. Ex Parte Jackson, 263 F. 110 (D. Mont. 1920).

64. Cf. Sparks v. United States, 90 F.2d 61 (6th Cir. 1937).

65. 392 U.S. 1 (1968).

66. People v. Coffey, 67 Cal. 2d 204, 60 Cal. Rptr. 457, 430 P.2d 15 (1967), refused to apply to such a detention the California statute abolishing the right to resist an unlawful arrest. It does not follow that when such a detention is constitutionally permissible, resistance is justified. 
will not have a great impact on the right to resist an unlawful arrest. Temporary detention, even when unfounded, is not so provocative as an arrest. Although no empirical research exists to verify the point, in the author's experience, stop-and-frisks do not generally provoke resistance. Furthermore, there must be some evidence for the officer to rely on. Vague as the term "reasonable suspicion" is, the Supreme Court $^{67}$ and commentators ${ }^{68}$ have emphasized that the officer cannot rely on subjective good faith, but must produce facts related to a serious crime which bring about a reasonable inference warranting the intrusion. Nevertheless, it will be possible, in some instances, for the police successfully to charge an individual with resisting detention instead of resisting arrest, because less evidence is required to detain.

Although it is difficult to delineate what is sufficient provocation to excuse an individual who resists a street detention, ${ }^{63}$ certain standards do exist. When the stop and frisk is shown to be a form of harassment directed against a defendant or a group to which he belongs, it is a provocative detention. Thus, for example, there is provocation if the stop is part of a pattern of "aggressive patrol," involving routine and random stops in a ghetto neighborhood, or if it is intended simply to enforce the officer's authority with teenagers, "hippies," or others in the neighborhood, or if it is only one of a series of fruitless stops directed against the defendant. ${ }^{70}$

\section{B. Face-to-Face Disputes ${ }^{71}$}

The paradigm case in which the right to resist unlawful arrest is an issue is posed by a typical street incident: A policeman sees a group of men on a corner and tells them to move on. One of them refuses, and gives the policeman an argument. In order to maintain his authority, the policeman arrests the man. ${ }^{22}$ Such arrests are not uncom-

67. Terry v. Ohio, 392 U.S. 1, 21-22 (1968).

68. LaFave, Street Encounters and the Constitution, 67 MIrch. L. REv. 39, 68-84 (1968). The New York City Police Department requires the submission of a form, UF250 cxplaining the grounds for a stop.

69. LaFave argues that such resistance is never justified. Id. at $125 \mathrm{n} .438$.

70. See Terry v. Ohio, 392 U.S. 1, 14 n.11 (1968); P. Chevicwr, Porice Power, ch. 12 (1969).

71. In most cases, arrests for misdemeanors will result from face-to-face disputes. A lawful arrest for a misdemeanor can generally be made without a warrant only if the crime is committed in the presence of the officer or if the officer has reasonable cause to believe that a crime is being committed in his presence. See, e.g., N.Y. CODE OF Crumival. Prockdures \$ 177(1) (MCKinney 1960). A felony arrest may be made without a marrant upon reliable information that a felony has been committed and that the defendant committed it. In practice most felony arrests do not stem from ficc-lo-face confrontations between the officer and the suspect.

72. Cf. Wimburley v. State, 30 Ala. App. 394, 6 So. 2d 524 (1942); Finch v. State, 101 Ga. App. 73, 112 S.E.2d 824 (1960). 
mon, especially in the cities where a great deal of police patrol consists of "moving people along."73 One study, for example, revealed that over one-fifth of all the disorderly conduct arrests in the District of Columbia resulted from words uttered to the officer alone. ${ }^{74}$ Investigators for the President's Commission on Law Enforcement and the Administration of Justice also found such practices to be very common. ${ }^{75}$ One example-less confusing and acrimonious than mostappears in the testimony of a police inspector concerning the arrest of two teenagers for disorderly conduct:

Well, I had observed we had some trouble in the area and I was down there. We had a detail along the Merrick Road trying to break up these small clusters of young people that were around on the Merrick Road and I observed Patrolman Johnson talking to this group of boys that included these two defendants. He had moved them from one place to another but they wouldn't leave this particular shopping center. I went over to the boys and I said: "Now you'll have to go home." And one boy, the Ortmann boy, said: "We don't have to." I said, "You have to leave now or you'll be arrested." He said: "Now, I want to talk to you." And I said: "I don't want to talk about it. You have to leave." And he repeated: "I want to talk to you." And I told Patrolman Johnson to take him in.

Q. What, if anything, did the defendant Pearsall say?

Well, while Patrolman Johnson was bringing the Ortmann boy to the car I said to the group in general, "You'll have to break it up and go home." And the Pearsall boy said: "I want to ask you something." And I said: "I don't want to answer anything or discuss anything, you must leave." And he said again: "I want to ask you something." And I said: "Take him to the car." We brought him into the stationhouse. ${ }^{76}$

73. Such cases are especially common in a populous state like New York. Sec, e.g., People v. Bomboy, 32 Misc. 2d 1002, 229 N.Y.S.2d 323 (Sp. Sess. 1962); Pcoplc v. La Sister, 9 Misc. 2d 518, 170 N.X.S.2d 702 (Sp. Sess. 1958); People v. Tinston, 6 Misc. 2d 485, 169 N.Y.S.2d 554 (Magis. Ct. 1957). Cf. People v. Gaskin, 305 N.Y. 837 (1954); People v. Drcarcs, 15 App. Div. 2d 204, 221 N.Y.S.2d 819 (1961), aff'd 11 N.Y.2d 906 (1962).

74. Hoffman and Wald, Report on the Disorderly Conduct Statute of the Dist. of Columbia (mimeograph, 1966).

75. Pres. Comm. ON Law ENForcement and the AdMin. of Justice, TASK Fonce RE. PORT ON THE POLICE, 179-180 (1967).

76. People v. Ortmann, No. 3108-3109/68 (D.C. Nassau County, N.Y.) Pt. III, Trial Minutes $10 / 17 / 68$. Defendants were acquitted of a charge of disorderly conduct under N.Y. Penal Law \$ 240.20(6) (McKinney 1967):

A person is guilty of disorderly conduct when, with intent to cause public inconA person is guilty of disorde, annoyance, or alarm, or recklessly creating a risk thercof: . . He congrcvenience, annoyance, or alarm, or per persons in a public place and refuses to comply with a lawful order of the police to disperse. 
The defendants here did not resist, but in similar cases, a defendant may pull his hands away from the handcuffs or push or hit the officer. In some cases, depending on the words used in the argument, the personality of the policeman, and the status of the defendant in the community, the policeman may use force in the arrest even without any resistance. In these circumstances, the defendant is commonly charged with breach of the peace as well as resisting arrest.

The important element in such cases is that the evidence for the underlying arrest, the breach of the peace, is based upon a face-to-face confrontation between the policeman and the citizen. The citizen knows perfectly well whether the arrest is false and arbitrary because he and the policeman have been present during every moment of the event. Both parties know all there is to know about the case. At a trial on the underlying charge, the version of the facts given by the defendant may be controverted by the policeman testifying to some actual disturbance of the peace. When the defendant's "day in court" is simply a swearing contest between the policeman and himself, the court will nearly always accept the policeman's version. But even if the judge accepts the defendant's story and dismisses the underlying charge, the court could convict for resistance to the illegal arrest unless the right to resistance is recognized.

There is a very practical consideration for permitting resistance to an unlawful arrest resulting from a face-to-face dispute. Defiance of a policeman's unlawful order may provoke $a$ blow as well as a false arrest. The defendant's alleged "resistance" may be non-existent or directed only to the use of excessive force. If there is no right to resist, a court cannot acquit on the resisting charge except by branding the policeman a liar. Where there is a right to resist, the factual question may be enveloped in the much easier question of the lawfulness of the arrest. More than eighty years ago, one court put it this way in a jury charge: The officer could arrest only for a breach of the peace actually
being committed in his presence and if you believe, from all the evidence in the case, that no such breach of the peace took place until the arrest was made, and then only in resisting the arrest,
such resistance was justifiable ${ }^{77}$ Of course, there is sometimes a dispute about the circumstances of 
the breach of the peace as well as of the resistance, but it is often easier for the court to determine whether there has been an unlawful arrest, instead of whether or not the police first used force, or used excessive force. When reasonable resistance to an unlawful arrest is justified, it may not be necessary to make the second determination at all.

What sort of "provocation" to resistance is made out by the actions of the police in the paradigm, face-to-face case? The policeman has initiated the situation, has confronted the citizen with an utterly arbitrary order, and has enforced it by an act of coercion intended primarily to maintain his authority. Such an arrest makes it difficult for any person who values his liberty to submit. The intent of the citizen in refusing to submit or in struggling is not criminal, but rather an intent to protest an injustice and to reject an arbitrary action. The resistance is an act which, but for the acts and encouragement of the police, would never have occurred. Analytically, this "provocation" has an effect similar to entrapment: The police have caused a "crime," where none would otherwise have occurred, by a "temptation" which the citizen should not be expected to resist, and under circumstances where there is no real criminal intent. ${ }^{78}$

This analysis points to a number of policies underlying the rule permitting resistance to arbitrary arrest in face-to-face confrontations. The rule, like the defense of entrapment, is partly intended to discourage police abuses. There is always the possibility that a malicious or ambitious policeman may be determined to convict a particular individual. If the policeman cannot arrest the citizen in a lawful way, he may do it in an arbitrary way. If he can provoke his victim to resistance, he can obtain a conviction for the resistance, if not upon the underlying charge. The more outrageous the arrest, the more likely it is to provoke resistance and lead to a conviction; the fact that there is no right to resist puts a premium on arbitrary police action.

The courts and legislatures have had no difficulty with a policy intended to discourage arbitrary police action. They have hesitated, however, over whether it ought to be enforced by self-help in the streets. As indicated above, that perspective distorts the problem; the question really is whether such self-help ought to be made a crime. If the provocation is enough to make a person who would not other-

78. See, e.g., Kansas City v. Mathis, 409 S.W.2d 280 (Kan. Gity Ct. App. Mo. 1966). Cf. Cox v. Louisiana, 379 U.S. 559 (1965). 
wise commit a crime resist arrest, then there is only one possible answer to the question.

The flaw in the statutes and court decisions which purport to abolish the right to resist is that they create a situation where the citizen is trapped by the legal system. If he obeys a patently arbitrary arrest, he has submitted to oppression, and if he resists, he may be convicted for his resistance. Surely there can be no more embittering experience of the criminal process than such a conviction. The freedom to refuse to obey a patently unlawful arrest is essential to the integrity of a government which purports to be one of laws, and not of men. Unless it is desirable to kill the impulse to resist arbitrary authority, the rule that such an arrest is a provocation to resist must remain fundamental.

\section{Other Patently False Arrests}

There are a number of cases in which the right to resist is less clearcut than in the face-to-face dispute, although there may still be considerable provocation. The problem is to distinguish between provocative arrests and those which are merely technically defective. $\mathrm{A}$ bystander sometimes sees a face-to-face dispute developing, intervenes in the illegal arrest, and is himself arrested and charged with obstructing an officer. According to the traditional American rule, a third person stands in the shoes of the person arrested, and can resist if the latter might have done so. ${ }^{79}$ Logically the right to interfere should be limited to persons who are actually privy to the circumstances out of which the original arrest arose. Put another way, there is sufficient provocation if the bystander is provoked by the same acts as the person arrested.

An arrest made on the complaint of a third party presents greater difficulty in justifying resistance. In most jurisdictions, a police officer is not supposed to arrest for a misdemeanor unless he has reasonable cause to believe he has seen the offense committed, ${ }^{80}$ but officers sometimes make such arrests and often make arrests for felonies solely upon the complaint of another citizen. Where the arrest is made on a third-

79. For the American rule, see Commonwealth v. Crotty, 92 Mass. (10 Allen) 403 (1865); People v. Papp, 185 N.Y.S.2d 907 (N.Y. County Ct. 1959). The English rule, as originally expounded in The Queen v. Tooley, 2 Ld. Raym. 1297, 92 Eng. Rep. 349 (K.B. 1710), seems now to be more like the rule advanced here. See pp. 1130.31 supra. The by: stander sometimes gets into his own face-to-face dispute by his verbal protests to the
officer.

80. E.g., N.Y. Code of Crmar. Proc. \$ 177 (McKinney 1960); see 39 U. of Detrort L.J. 595 (1962). 
party complaint, the element of personal antagonism and deliberate oppression is less likely to be involved, and such an arrest is thus usually less provocative than an arrest where the officer himself is the complainant. ${ }^{81}$ There is no hard and fast rule for arrests based on thirdparty complaints, but there are several instances in which such arrests will be sufficiently provocative to justify a right to resist. ${ }^{82}$

Lack of an underlying offense. If the officer charges the citizen with acts which do not constitute an offense, then the officer himself should realize that the arrest cannot be lawful. Despite his reliance on the complaint of the third person, there will be considerable provocation. These cases appeared frequently at common law. ${ }^{83}$

Officer's knowledge that the complaint is false. When an officer comes to make an arrest on the complaint of a third person and the defendant presents evidence which would tend to show that the arrest is unlawful, some provocation is engendered if the policeman proceeds to arrest. This hypothetical case is not as fanciful as it may seem. When making an arrest in which they have no direct interest, policemen frequently tell the defendant the source of and reason for the complaint. It is also common for the defendant to attempt to convince the officer not to make the arrest. In City of Columbus v. Holmes, ${ }^{84}$ when an officer came to demand the complainant's car keys from the defendant, defendant showed proof of ownership of the car. The officer ought to have paused to consider the reasonableness, if not the legality, of an arrest. Once a defendant has explained the illegality of the arrest, he may be justifiably outraged if the officer persists in his course.

81. State v. Koonce, 89 N.J. Super. 169, 214 A.2d 428 (1965), which changed the law of resisting unlawful arrest in New Jersey, arose out of an arrest for selling liquor to a minor in which the officer saw the minor with the liquor, but not the sale.

82. Courts have not always applied the rule of provocation to arrests based on third party complaints. Some have instead applied a very mechanical rule; if the arrest is illegal, resistance is justified. For example, in Commonwcalth v. Carey, 66 Mass. (12 Gush) 246 (1853), constable encountered the defendant near an office door that had been forced open. He searched the defendant and found a chisel. When the officer then made an one defendant attempted to escape, killing the constable in the process. The crime of breaking an office door was not a felony, and because the constable had not seen the defendant commit it, Chief Justice Shaw instructed the jury that it could find man. slaughter.

A similar result was reached in the case of State v. Robinson, 6 Ariz. App. 424, 483 P.2d 75 (1967). The defendant was convicted of obstructing an officer when he resisted an arrest for burglary. The appellate court reversed because the arrest was based entircly on an anymous telephone tip and was therefore illegal. The defendant was allowed to resist regardless of whether or not he was provoked. Decisions such as these, which ignore the key factor of provocation, are one cause of the recent unpopularity of the right to resist an unlawful arrest.

83. See notes 13 and 14 supra. See also City of Monroe v. Ducas, 203 La. 974, 14 So. 2d

781 (1943). 152 N.E.2d 301 (Franklin County Ct., Ohio 1958), aff'd, 169 Ohio St. 251, 159 N.E.2d 232 (1959). 
Personal animosity. Policemen sometimes threaten to "get" a defendant, and they may use the complaint of a third party as a pretext. If the arrest is unlawful, a personal element makes it doubly provocative, and suggests that the police may have entrapped the resisting defendant into a crime he would not otherwise have committed.

Repeated arrests. Repeated false arrests, especially after the victim has once been found innocent, are especially provocative. There is an implied element of personal revenge, and a suggestion that the officer has made the arrest knowing it to be illegal. Repeated false arrests may well lure the defendant into resistance. ${ }^{85}$ For example, the author defended two young men who had been arrested for stealing candy from a concessionnaire and then released after the police found that they had paid for the candy. The concessionnaire was incensed by their rude behavior, and persuaded the police to pursue and arrest them. Having once released them because the facts demonstrated their innocence, it was highly provocative to rearrest them. ${ }^{80}$ The use of raids or dragnet arrests against a whole class of supposed undesirables presents a similar case. This kind of action is taken by the authorities with disturbing frequency, often with the support of elected officials, as a method of systematic harassment without a pretense of probable cause. A notorious example is the wave of police repression against radicals following the "Palmer Raids" of 1919-20. One federal judge remarked that "the inalienable right and law of self-defense justified resistance to the last dread extremity." 87

All of the above cases, in which arrest was made without a warrant on the complaint of a third person have some elements in common. In each, the officer has good reason to know both that the arrest is unlawful and that the defendant is likely to be provoked by it. In the interest of discouraging the practice of manufacturing a conviction by luring a defendant into resistance-creating a crime which would not otherwise occur-reasonable resistance to such an arrest should be excused.

Written process. Traditionally resistance to unlawful arrest was part of the broader problem of resistance to legal process in general. ${ }^{89}$ It

85. Kansas City v. Mathis, 409 S.W2d 280 (Kan. City Ct. App. Mio. 1960) (repeated false arrest on a charge of being a known prostitute; last time around, the defendant re. sisted).

86. People v. Williams, No. B10274-76/68 (Crim. Ct. of the City of New York, Mran. hattan). This case was decided after the "no sock" law, supra note 31, was passed. The acquittal of the crime of resisting arrest was based on the court's acceptance of the argument that non-violent resistance (pulling away) to an obviously unlawful arrest was not forbidden by the statute.

87. Ex Parte Jackson, 263 F. 110, 111 (D. Mfont. 1920). For more recent eximples, sec P. Chevigny, Police Povver, ch. 12 (1969).

88. Annot., 10 A.L.R.3d 1146 (1966). 
is questionable today if resistance to written process may ever be justified. ${ }^{89}$ Process issued by a court stands in a fundamentally different position from a police order. In a few cases, however, the common law seems to have recognized the right to resist, as in the case of an obviously fraudulent warrant, such as a warrant filled in by the police, 0 or as in the case of an arrest warrant which does not describe any defendant, or a search warrant which does not describe the premises to be searched.91 These are cases in which the process is not genuinely that of a court or in which neither the officer nor the defendant could believe that the process was proper. They cover the few cases in which officers may use unauthorized written process for oppressive purposes. The interest in enforcing such process is minimal, the abuse great, and the provocation great as well. Apart from these cases, it appears that an individual must comply with the process and resort to the courts to attack it.

Undoubtedly, it is sometimes difficult to determine when the right to resist an unlawful arrest exists. The task is not impossible, however, and it is certainly consistent with fundamental fairness to excuse persons who are provoked to reasonable resistance by oppressive and unlawful state action. The purpose of the right is not to encourage violent attacks on policemen, but to preserve the sense of personal liberty inherent in the right to reject arbitrary orders. To permit the police to provoke individuals into committing the crime of resisting arrest, creates a trap for citizens which must, in the long run, injure the integrity of the legal system.

89. Cf. Walker v. City of Birmingham, 388 U.S. 307 (1967), which holds that an injunction which is not transparently invalid must be obeyed until it is struck down by a court.

90. E.g., Rafferty v. People, 69 Ill. 111 (1873). However, in Rafferty the court again applied the mechanical rule that an illegal arrest justifies resistance; there was no showing that the defendant knew that the warrant was false.

9 . E. Commonwealth v. Crotty, 92 Mass. (10 Allen) 403 (1865), where a magistrate issued a warrant for the arrest of "John Doe or Richard Roe" bearing no address, description or any other information about the defendant. See also Jackson v. Statc, 87 Fla. 262, 99 So. 548 (1924). 